\title{
PERTANGGUNGJAWABAN POLITIK PRESIDEN PASCA AMANDEMEN UUD 1945
}

\author{
Hendra \\ Departemen Ilmu Politik, FISIP Universitas Padjadjaran \\ E-mail: hendra_ip@yahoo.com
}

\begin{abstract}
ABSTRACK
After the UUD 1945 amendment, there is fundamental change in the Indonesian governmental system. This changes well-marked with the facts that after amandement there is an alteration to the patern of president or vice president election, and the regulation of the relation between president and DPR. This changes has influence the president political responsibility after amandement.
\end{abstract}

Key words: democracy, distribution of power, presidency, governmental system, political responsibility

\begin{abstract}
ABSTRAK
Setelah dilakukannya amandemen UUD 1945, terjadi perubahan fundamental dalam sistem pemerintahan Indonesia. Perubahan tersebut ditandai dengan fakta bahwa setelah amandemen terjadi perubahan pola pemilihan presiden dan wakil presiden, dan aturan tentang relasi antara presiden dan DPR. Perubahan tersebut telah mempengaruhi pertanggungjawaban politik presiden pasca amandemen.
\end{abstract}

Kata kunci: demokrasi, pembagian kekuasaan, lembaga kepresidenan, sistem pemerintahan, pertanggungjawaban politik

\section{PENDAHULUAN}

Sejak berdirinya Negara Kesatuan Republik Indonesia tanggal 17 Agustus 1945 sampai sekarang, Indonesia telah diperintah oleh enam orang presiden mulai dari Ir. Soekarno, Soeharto, B.J. Habibie, Abdurrahman Wahid, Megawati sampai dengan Susilo Bambang Yudhoyono. Ada yang menarik dalam sejarah perpolitikan di Indonesia terutama pada saat pergantian presiden. Empat dari enam presiden yang pernah berkuasa di Indonesia, berakhir dengan cara yang tidak lazim.

Faktor penyebab ketidaklaziman proses peralihan kekuasan dan ketidakjelasan pertanggungjawaban politik presiden di Indonesia karena kelemahan pada konstitusi yang berlaku pada masa itu. UUD 1945 tidak mampu mengkontruksikan hubungan secara balance of power antara presiden dengan lembaga tinggi negara yang lain. Baik pada masa Soekarno maupun pada masa Soeharto, UUD 1945 telah menjadi instrumen yang ampuh untuk membenarkan berkembangnya otoritarianisme kekuasaan di lingkungan lembaga kepresidenan. Lembaga seperti DPR dan MPR tunduk dan berada di bawah bayang-bayang kekuasaan presiden. Sebaliknya pada masa Presiden Habibie dan Abdurrahman Wahid, pelaksanaan UUD 1945 memberikan kesempatan pada DPR dan MPR untuk mengalahkan presiden. Begitu pula dengan sistem pemerintahan yang dianut,UUD 1945 tidaktegas dalammenentukan apakah sistem pemerintahan yang digunakan presidensil, parlementer atau campuran. Karena, jika ditelaah secara seksama sistem pemerintahan presidensiil yang dianut dalam UUD 1945 sama sekali tidak murni sifatnya. Artinya, sistem pemerintahan yang dianut juga mengandung adanya unsur parlementer. Salah satu ciri pokok sistem parlementer dalam UUD 1945 adalah berkenaan dengan pertanggungjawaban presiden kepada MPR, sebagai lembaga parlemen yang mempunyai kedudukan sebagai lembaga tertinggi negara. (CPSS, 2002:6).

Dengan mendasarkan pada kenyataan tersebut, MPR hasil pemilu 1999 kemudian mengagendakan pelaksanaan amandemen terhadap UUD 1945. Realisisasi amandemen dilaksanakan sebanyak empat kali, yaitu pada tahun 1999, 2000, 2001 dan 2002. Amandemen 
dilakukan secara fundamental dengan berorientasi pada upaya menciptakan sistem politik yang lebih demokratis menyangkut eksistensi kedaulatan rakyat, jaminan hak asasi warga negara serta hubungan kekuasaan antar lembaga negara.

Salah satu aspek penting yang mengalami perubahan pada UUD 1945 adalah sistem pemerintahan yang dianut oleh Indonesia. Secara konseptual UUD 1945 setelah amandemen dapat dikatakan menganut sistem pemerintahan presdensil secara murni. (Jimly Ashidiqie dalam Firdaus, 2007:2). Pendapat tersebut didasari oleh terjadinya perubahan terhadap pola pemilihan presiden/wakil presiden, pembatasan masa jabatan presiden, pengaturan hubungan kekuasaan antara presiden dan DPR dan pengaturan pada kekuasaan presiden. Tetapi, walaupun demikian, UUD 1945 pasca amandemen tidak secara eksplisit mengatur mengenai pertanggungjawaban politik presiden.

Berdasarkan uraian latar belakang di atas, penulis merasa tertarik untuk mengkaji dan mendalami pertanggungjawaban politik presiden di Indonesia berdasarkan perubahan pada sistem pemerintahan yang dianut setelah dilakukan amandemen terhadap UUD 1945. Adapun judul yang diajukan oleh penulis dalam penelitian ini adalah "Pertanggungjawaban Politik Presiden Pasca Amandemen UUD 1945".

\section{KERANGKA PEMIKIRAN}

Keberadaan demokrasi sangat ditentukan oleh kedaulatan rakyat atau dengan perkataan lain tidak ada demokrasi tanpa kedaulatan rakyat. Seperti dikemukakan oleh Kranenburg yang menilai demokrasi sebagai cara rakyat memerintah dalam negara (Firdaus, 2007:10).

Pelaksanaan kedaulatan rakyat melalui demokrasi dalam praktiknya diwujudkan secara beragam di berbagai negara, baik melalui sistem perwakilan maupun sistem pemilihan langsung. Penyebutan sistem demokrasi langsung paling banyak digunakan untuk menunjukkan cara pembentukan kekuasaan lembaga negara yang dipilih langsung oleh rakyat sebagai pemilik kedaulatan, sedangkan sistem perwakilan merupakan perwujudan demokrasi dan kedaulatan rakyat secara tidak langsung melainkan melalui suatu lembaga perwakilan yang dimandatkan oleh rakyat untuk melaksanakan kedaulatan (Firdaus, 2007:10-11).
Pembentukan kekuasaan maupun pemberian mandat oleh rakyat sebagai pemegang kedaulatan tidak serta merta dapat memberikan jaminan bahwa kekuasaan yang dimiliki oleh pemegang kekuasaan tersebut tidak disalahgunakan. Hal ini antara lain didasarkan pada kenyataan empiris bahwa pemegang kekuasaan adalah manusia yang dengan segala kelebihan dan kekurangannya cenderung selalu menyalahgunakan kekuasaan tersebut. Berkenaan dengan hal itu, patut direnungkan kembali ungkapan yang dikemukakan Lord Acton, seorang ahli sejarah Inggris yang mengatakan power tends to corruptbut absolute power corrupts absolutely" (Lord Acton dalam Tim CPSS, 2002:73). Oleh karena itu, untuk menyempurnakan pelaksanaan demokrasi itu sendiri diperlukan intrumen pendukung yang dapat membatasi, mengendalikan dan mengontrol kekuasaan tersebut.

Gagasan untuk membatasi kekuasaan sebenarnya sudah berkembang pada masa demokrasi konstusional abad ke 19. Menurut paham ini cara yang terbaik untuk membatasi kekuasaan pemerintah ialah dengan suatu konstitusi, apakah ia bersikap naskah (written constitution) atau tak bersifat naskah (unwritten constitution). Bagi mereka yang memandang negara dari sudut kekuasaan dan menganggapnya sebagai organisasi kekuasaan, maka konstitusi atau Undang-Undang Dasar dapat dipandang sebagai lembaga atau kumpulan asas yang menetapkan bagaimana kekuasaan dibagi antara beberapa lembaga kenegaraan. Meminjam teori Montesquie, guna mencegah terjadinya absolutisme kekuasaan maka kekuasaan tersebut harus terpisah menjadi tiga cabang, yaitu kekuasaan legislatif (pembuat undang-undang), eksekutif (pembuat undang-undang dan yudikatif (pelaksana peradilan). Seiring dengan berkembangnya konsep Negara kesejahteraan (welfare state), penafsiran trias politica tidak lagi diterima sebagai pemisahan kekuasaan, tetapi pembagian kekuasaan, dimana hanya fungsi pokoknya yang dibedakan menurut sifatnya serta diserahkan kepada badan yang berbeda (distinc hands), tetapi untuk selebihnya kerjasama diantara fungsi-fungsi tersebut tetap diperlukan untuk kelancaran organisasi.

Salah satu cabang kekuasaan yang penting dalam negara adalah eksekutif yang kekuasaannya dipegang oleh badan eksekutif. Di negara- 


\section{METODE PENELITIAN}

Dalam mengkaji pertanggungjawaban politik presiden pasca amandemen UUD 1945, metode penelitian yang digunakan oleh peneliti adalah metode kualitatif. Alasan menggunakan metode penelitian kualitatif dikarenakan penelitian yang dilakukan merupakan fenomena yang belum banyak diketahui. Untuk memperoleh data yang diperlukan, penelitian dilakukan dengan metode deskriptif analisis, yaitu suatu tipe penelitian yang berusaha melukiskan realitas sosial yang komplek melalui penyederhanaan dan klasifikasi dengan memanfaatkan konsepkonsep yang bisa menjelaskan suatu gejala sosial secara analitis (Vredenbregt,1983:34-35). Karena tujuan penelitian adalah menyederhanakan realitas sosial, khususnya realitas politik yang kompleks, maka penelitian ini dilakukan secara kualitatif.

Menurut Lofland dan Lofland yang dikutif oleh Maleong, sumber data utama dalam penelitian kualitatif ialah kata-kata dan tindakan, selebihnya adalah data tambahan seperti dokumen, dan lain-lain. Dalam penelitian ini data jenis data yang digunakan adalah kata-kata dan sumber data tertulis (Lofland dan Lofland dalam Maleong, 2006:57).

Sesuai dengan karakteristik yang dikemukakan di atas, maka sumber data dipilah menjadi dua bagian, yaitu sumber data primer dan sumber data sekunder. Data primer adalah data yang diperoleh secara langsung dan atau melalui wawancara dengan informan (responden). Sedangkan data sekunder adalah sumber tertulis yang merupakan data tambahan/ sekunder yang diperoleh dari buku, majalah ilmiah, sumber data arsip, dan dokumen resmi.yang dijaring melalui studi pustaka.

Data yang diperlukan dalam penelitian ini dikumpulkan melalui dua teknik pengumpulan data, yaitu:

1. Studi pustaka, yaitu penelusuran terhadap sumber-sumber tertulis, baik buku, laporan pers, berbagai pendapat dan analisis atasnya, maupun dokumen yang berkaitan dengan substansi penelitian.

2. Wawancara mendalam dengan para narasumber yang mampu memberikan informasi yang luas dan mendalam mengenai pertanggungjawaban politik presiden pasca amandemen UUD 1945 yang mencakup kalangan akademisi yang dianggap memiliki pandangan netral, anggota DPR/MPR dan yang memiliki hubungan kekuasaan terhadap lembaga kepresidenan. Wawancara dilakukan dengan menggunakan pedoman wawancara (interview guide) yang telah dipersiapkan sebelumnya.

Data dan informasi yang dijaring dengan berbagai instrumen dalam studi ini akan berupa tumpukan-tumpukan data mentah. Tidak semua data mentah itu dipindahkan ke dalam laporan penelitian, melainkan perlu diorganisir, dipilah, dikelola, disintesiskan dan diceritakan kepada orang lain. Jadi data yang diperoleh di lapangan sebagai bahan "mentah" disingkatkan, direduksi, disusun lebih sistematis ditonjolkan pokokpokok yang penting, diberi susunan yang lebih sistematis sehingga lebih mudah dikendalikan.

Untuk memeriksa keabsahan dari data yang diperoleh, penulis menggunakan teknik triangulasi. Triangulasi merupakan teknik pemeriksaan keabsahan data yang memanfaatkan sesuatu yang lain di luar data itu untuk keperluan pengecekan atau sebagai pembanding terhadap data itu. Teknik triangulasi yang banyak digunakan ialah pemeriksaan melalui sumber lainnya. Triangulasi dengan sumber berarti membandingkan dan mengecek balik derajat kepercayaan suatu informasi yang diperoleh melalui waktu dan alat yang berbeda dalam penelitian kualitatif(Maleong, 2006:330).

\section{SISTEM PEMERINTAHAN PASCA AMANDEMEN UUD 1945}

Salah satu aspek penting yang menentukan penyelenggaraan kekuasaan dalam negara adalah sistem pemerintahan yang dianut oleh suatu negara. Bangsa Indonesia telah mengadakan eksperimen yang cukup lama dalam penerapan sistem pemerintahan parlemen dan sistem pemerintahan campuran, tetapi keduaduanya terbukti gagal membangun sistem politik yang demokratis dan mewujudkan keadilan bagi seluruh warga negara. Memang banyak teori berkenaan dengan ini dan banyak pula para ahli tidak menolak kesimpulan yang menyatakan bahwa sistem parlementer telah gagal dipraktekkan. Namun dalam kenyataan sejarah, kesulitan-kesulitan yang timbul sebagai akibat penerapan sistem parlementer di masa-masa awal kemerdekaan tidak 
yang dapat mengalahkan lembaga lain. Jika DPR terlalu ketat mengawasi bahkan ikut campur menentukan dan membatasi hak prerogatif presiden maka dikhawatirkan sistem pemerintahan presidensial bergeser menjadi sistem pemerintahan parlementer dimana parlemen menentukan setiap kebijakan yang dilakukan oleh presiden.

Selain kekuasaan presiden dibatasi oleh adanya pengurangan dan pembatasan oleh DPR, kekuasaan presiden juga dibatasi dengan masa jabatan. Dalam Pasal 7 UUD 1945 disebutkan "Presiden dan Wakil Presiden memegang jabatan selama masa lima tahun, dan sesudahnya dapat dipilih kembali jabatan yang sama, hanya untuk satu kali masa jabatan". Sebelum UUD 1945 diamandemen tidak ada pembatasan semacam itu. Presiden berkuasa selama masih menyanggupi dan dipilih oleh MPR. Dalam prakteknya tanpa pembatasan kekuasaan presiden berkuasa dalam masa yang lama yang secara perlahan membentuk kekuasaan yang otoriter seperti halnya Soeharto pada masa Orde Baru.

\section{HUBUNGAN KEKUASAAN PRESIDEN DAN DPR}

Selain kedua ciri di atas, ciri lain yang terdapat dalam negara yang menganut sistem pemerintahan presidensial ialah presiden mempunyai kedudukan yang sejajar/sederajat dengan parlemen. Dalam kedudukan ini parlemen tidak dapat menjatuhkan Presiden dan wakil presiden dalam masa jabatannya. Begitu pula sebaliknya, Presiden tidak dapat membubarkan atau membekukan Parlemen.

Secara teoritis kesederajatan hubungan kekuasaan antara Presiden dan Parlemen dalam sistem pemerintahan presidensial dilandasi oleh prinsip cheks and balance. Prinsip Cheks and balance merupakan suatu asas dimana setiap cabang kekuasaan dapat mengawasi dan mengimbangi cabang kekuasaan lainnya. Dalam prinsip ini tidak ada lembaga yang lebih tinggi atau lebih kuat, tetapi kekuasaan yang setara. Kesetaraan ini memaksa semua kekuasaan yang ada dalam negara bersikap hati-hati dalam menggunakan kekuasaan yang dimilikinya dan membatasi kemauan-kemauan sendiri. Tidak ada suatu keputusan bisa dibuat tanpa mempertimbangkan kemauan-kemauan yang lain, sebab yang lain bisa membatalkannya dengan kekuasaan yang dimilikinya. Kontrol atas suatu lembaga dilakukan bukan untuk mengukuhkan suatu kewenangan tetapi untuk membuat pemerintah dapat bekerja secara efisien, efektif dan bertanggungjawab. (L. Sais Ruphina dalam CPPS, 2002:147)

Pasca perubahan UUD 1945, secara garis besar ada tiga hal pokok menyangkut hubungan kekuasaan antara Presiden dan DPR Pertama, hubungan legislasi (pembentukan undang-undang); kedua, hubungan dalam menetapkan Anggaran Pendapatan dan Belanja Negara (APBN) dan; ketiga, hubungan pengawasan. Selebihnya hubungan kekuasaan yang sifatnya insidental yang meliputi hubungan dalam membuat pernyataan perang, membuat perjanjian internasional yang menimbulkan akibat luas dan mendasar bagi kehidupan rakyat terkait keuangan negara, pengangkatan dan penempatan duta, pemberian amnesti dan abolisi serta pengangkatan pejabat-pejabat negara (anggota BPK, Hakim Agung, anggota Komisi Yudisial dan Hakim Konstitusi).

Dari hasil kajian terhadap ketiga hubungan kekuasaan antara Presiden dan DPR, penulis dapat menarik kesimpulan bahwa hubungan kekuasaan antara Presiden dan DPR pasca amandemen UUD 1945 tidak menggambarkan adanya prinsip cheks and balance. Dari ketiga hubungan tersebut, secara politik kedudukan DPR lebih kuat dibandingkan dengan pemerintah. Hal ini tentu saja bertentangan dengan prinsip yang ada pada sistem pemerintahan Presidensial yang mengharuskan terjadinya kesederajatan hubungan antara kedua lemabaga kekuasaan tersebut. Presiden akan mengalami kesulitan dalam menjalankan pemerintahan tanpa adanya dukungan dari DPR. Sebaliknya, jika dukungan DPR terhadap pemerintah terlalukuat maka DPR tidak akan berfungsi secara benar. Hubungan kekuasaan seperti itu tidak akan menghasilkan keseimbangan, tetapi berpotensi melahirkan pemusatan kekuasaan pada satu tangan.

Selainketigahubungankekuasaantersebut, UUD 1945 juga menentukankekuasaan presiden terkait dengan kekuatan militer, perang dan perdamaian, perjanjian internasional, keadaan bahaya, pengangkatan dan penerimaan duta dan konsul,pemberian grasi, amnesti, abolisi, dan rehabilitasi, serta pemberian tanda kehormatan. Kekuasaan-kekuasaan tersebutlah yang secara teoretis sering diasosiasikan sebagai kekuasaan kepala negara. Kekuasaan-kekuasaan tersebut 
Dalam perpolitikan Indonesia, pertanggungjawaban politik Presiden kepada rakyat merupakan suatu hal yang baru. Kebaruan ini tentunya menimbulkan berbagai pertanyaan yang harus segera mendapatkan jawabannya. Penulis mencatat, sedikitnya ada tiga pertanyaan terkait dengan pertanggungjawaban politik presiden kepada rakyat. Pertama tentang substansi yang dipertanggungjawabkan; kedua bagaimana mekanisme pertanggungjawaban tersebut dan; ketiga, bagaimana penerimaan dan penolakan pertanggungjawaban tersebut.

Di awal sudah dikemukakan bahwa UUD 1945 sebelum amandemen secara tegas menyebutkan bahwa presiden dalam menjalankan kekuasaannya berpedoman pada GBHN yang ditetapkan oleh MPR. GBHN ini menjadi parameter bagi MPR untuk menerima atau menolak pertanggungjawaban politik presiden selama menjalankan kekuasaannya. Tetapi setelah UUD 1945 mengalami perubahan, tidak ada satupun pedoman bagi presiden dalam menjalankan kekuasaannya. UUD 1945 hanya menyebutkan kekuasaan-kekuasaan yang dimiliki oleh presiden sebagai batasan untuk menjalankan roda pemerintahan. Dan ketika kekuasaan tersebut dijalankan, maka akan lahir berbagai kebijakan yang dalam bentuknya dapat berupa Undang-Undang, Peraturan Pemerintah Pengganti Undang-Undang, Peraturan Pemerintah, Peraturan Presiden, Keputusan Presiden dan kebijakan lainnya menyangkut kekuasaan eksekutif. Kebijakan-kebijakan inilah yang secara langsung akan dirasakan dan menyentuh kehidupan rakyat. Jadi, yang menjadi subtansi pertanggungjawaban politik presiden kepada rakyat adalah kebijakan-kebijakan yang dikeluarkan oleh presiden selama menjalankan kekuasaannya yang secara langsung dirasakan oleh rakyat. Secara lebih luas Rusadi Kantaprawira bahkan menyebutkan:

Pertanggungjawaban politik presiden tidak hanya pada kebijakan, tetapi juga segala macam perilaku, tindakan dari presiden, bahkan bisa juga kalau dia tidak diperkenankan untuk dipilih kembali karena masa jabatannya sudah habis, orang lain yang berasal dari partainya yang running for the presidensial, yang mengikuti pemilihan presiden sebagai pengganti presiden yang sudah habis masa jabatannya. Kalau dia terpilih dari figur partai tersebutmaka rakyat menghendaki kontinuitas kebijakan ala partai tersebut. (Kantaprawira, wawancara tanggal 3Mei 2009)

Kedudukan presiden dalam sistem presidensial kuat, artinya presiden tidak dapat dijatuhkan karena kebijakan yang dikeluarkannya, kecuali terjadi hal-hal khusus yang telah ditentukan sebelumnya oleh konstitusi, misalnya presiden melakukan tindakan kriminal atau terang-terangan melanggar konstitusi. Selama presiden dianggap tidak melakukan pelanggaran terhadap ketentuan tersebut, presiden dapat menjalankan kekuasaannya selama lima tahun. Kedudukan presiden dalam sistem pemerintahan presidensial bersifat fixed term in office. Oleh karena itu, agar kebijakan-kebijakan yang dikeluarkan oleh presiden tidak menimbulkan terjadinya penyalahgunaan kekuasaan, maka kekuasaan tersebut harus dibatasi dan dikontrol oleh lembaga lain.

Di dalam presidensialisme, mandat dari rakyat terbagi dalam eksekutif dan legislatif. Lembaga yang terakhir ini mempunyai kekuasaan untuk membentuk undang-undang, menyusun anggaran dan mengawasi kebijakan-kebijakan yang dijalankan oleh pemerintah. Keberadaan lembaga ini menjadi penyeimbang bagi presiden ketika menjalankan kekuasaannya. Tetapi, perlu diingatkan bahwa kekuasaan yang dimiliki oleh DPR tidak dapat menjatuhkan kekuasaan presiden seperti halnya mosi tidak percaya dalam sistem parlementer. Kontrol atas kekuasaan presidenpun dilakukan bukan untuk mengukuhkan dominasi DPR, tetapi untuk membuat pemerintah dapat bekerja secara efisien, efektif dan bertanggungjawab. Hubungan kekuasaan antara Presiden dan DPR dalam sistem presidensial dibangun berdasarkan prinsip kesederajatan yang dilandasi oleh saling mengawasi dan saling menyeimbangi (cheks and balances).

Sayangnya, seperti dalam kajian terhadap hubungan kekuasaan antara Presiden dan DPR, UUD 1945 pasca perubahan tidak mampu mengkonstruksikan hubungan kedua lembaga tersebut berdasarkan prinsip cheks and balance. Karena kuatnya DPR, secara politis presiden memiliki ketergantungan yang sangat tinggi terhadap dukungan DPR. Dalam prakteknya, keadaan ini telah menimbulkan penyalahgunaan kekuasaan dalam bentuk kolusi antara pemerintah denganDPR. Pemerintah berupaya agar berbagai 
negara yang demokratis badan eksekutif biasanya terdiri dari kepala negara seperti raja atau presiden, beserta menteri-menteri. Menurut tafsiran tradisional ajaran trias politica, tugas utama dari eksekutif adalah hanya melaksanakan atau menjalankan kebijakan-kebijakan yang telah ditetapkan oleh legislatif. Akan tetapi saat ini wewenang badan eksekutif jauh lebih luas daripada hanya sekedar melaksanakan undangundang. Kadang-kadang dalam Negara modern badan eksekutif sudah menggantikan badan legislative sebagai pembuat kebijakan yang utama.

Untuk memahami bagaimana keberadaan badan eksekutif dalam negara yang demokratis, maka secara umum kita melihat adanya dua macam badan eksekutif menurut sistem pemerintahan yang dianut. Pertama menurut sistem parlementer dan kedua menurut sistem presidensiil. Sekalipun demikian dalam pengelompokkan ini perlu diingat bahwa dalam setiap kelompok memiliki beberapa variasi.

Pada tahun 1999, 2000, 2001 dan 2002 Indonesia melakukan amandemen terhadap Undang-Undang Dasar 1945. Amandemen dilakukan karena dianggap sudah tidak sesuai dengan perkembangan politik di Indonesia. Pasca reformasi tahun 1998, masyarakat men-inginkan terwujudnya sistem politik yang demokratis. Banyak yang beranggapan bahwa transformasi ke arah pembentukan sistem politik yang demokratis hanya dimungkinkan bila didahului oleh perubahan fundamental dalam aturan konstitusi yang memberikan dasar bagi berbagai agenda demokrasi lainnya. Salah satu materi dalam perubahan terhadap UUD 1945 adalah ketentuan-ketentuan yang mengatur tentang sistem pemerintahan.

Setelah UUD 1945 diamandemen presiden tidak lagi dipilih oleh MPR, tetapi langsung dipilih oleh rakyat setiap 5 tahun sekali. Masa jabatan presiden pun dibatasi hanya sampai dua periode. Pembagian kekuasaan juga mulai ditata dengan mendasarkan pada cek and balance system dalam hubungan antara lembaga kepresidenan dengan lembaga tinggi negara lainnya. Secara konseptual UUD 1945 setelah amandemen dapat dikatakan telah secara murni menganut sistem pemerintahan presidensil.

Perubahan-perubahan padaberbagaiketentuan yang mengatur tentang sistem pemerintahan diatas secara implisit akan mempengaruhi pada pertanggungjawaban politik, khususnya yang berkaitan dengan pertanggungjawaban politik seorang presiden. Sehingga jika digambarkan dalam bentuk bagan, model kerangka pemikiran yang mendasari penulis untuk menganalisis tesis ini adalah sebagai berikut:

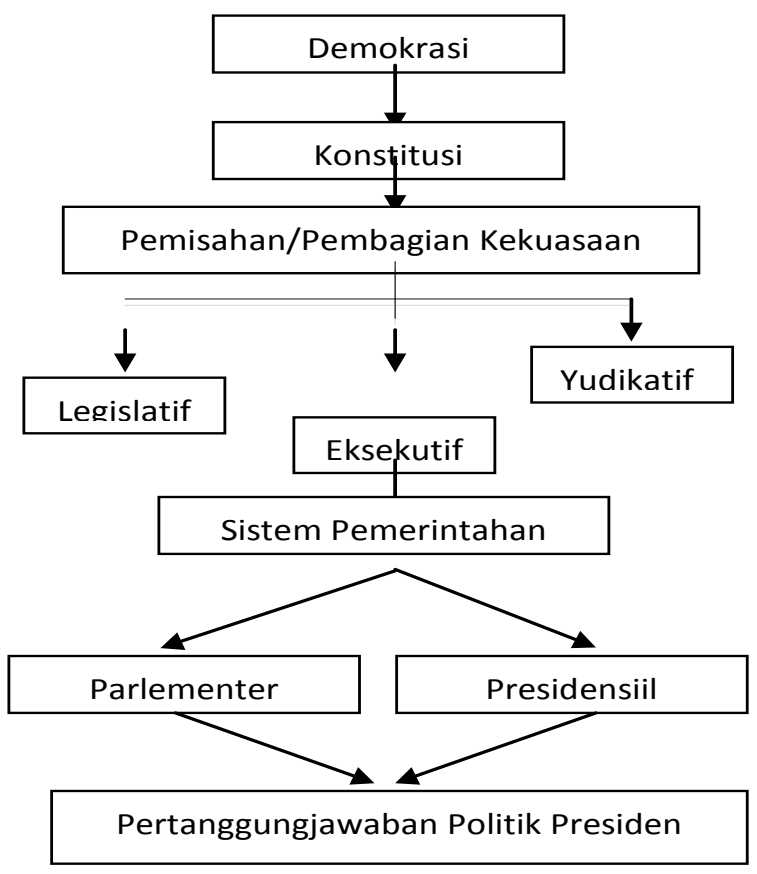

Gambar 1. Model Kerangka Pemikiran

Bagan diatas menjelaskan bahwa demokrasi merupakan sistem politik yang memberikan kemungkinan kepada rakyat untuk membentuk kekuasaan dalam negara berdasarkan aspirasinya. Agar kekuasaan yang sudah terbentuk tidak disalahgunakan, maka diperlukan adanya konstitusi sebagai instrumen untuk membatasi kekuasaan dalam negara. Konstitusi akan membagi kekuasaan dalam negara menjadi 3 cabang kekuasaan, yaitu eksekutif, legislatif dan yudikatif. Khusus mengenai cabang kekua-saan eksekutif, secara umum dapat dikaji berdasarkan sistem pemerintahan dari suatu negara. Secara umum sistem pemerintahan yang berlaku saat ini adalah sistem pemerintahan parlementer dan sistem presidensiil. Dari model sistem pemerintahan tersebut dapat diketahui bagaimana pertanggungjawaban politik seorang Presiden dalam suatu negara.

Dengan mendasarkan pada kerangka pemikiran di atas, penulis mengembangkan hipotesis kerja sebagai berikut: "Perubahan pada sistem pemerintahan yang dianut Pasca amandemen UUD 1945 akan mempengaruhi perubahan pertanggunggungjawaban politik Presiden”. 
dapat menutupi kenyataan bahwa Indonesia tidak berhasil dalam mempraktekkan sistem parlementer yang diidealkan. Karena itu, tidak mudah untuk merumuskan alasan lain untuk kembali mengidealkan penerapan sistem parlementer itu di Indonesia pada masa yang akan datang (Ashidiqqie dalam CPSS, 2002: 4546). Begitu pula dengan sistem pemerintahan campuran yang dianut oleh UUD 1945 sebelum diamandemen. Sistem tersebut menyebabkan Indonesia terjebak dalam sistem politik yang otoriter.

Pengalaman sejarah tersebut, membawa bangsa ini mencita-citakan suatu perubahan untuk mewujudkan suatu sistem pemerintahan yang mampu menciptakan sistem politik yang demokratis, yang dalam perkembangannya diakomodir dalam perubahan UUD 1945. Banyak kalangan berpendapat bahwa sistem pemerintahan yang dianut oleh Indonesia pasca perubahan UUD 1945 adalah sistem pemerintahan Presidensial murni. Pendapat tersebut didasari oleh terjadinya perubahan terhadap pola pemilihan presiden/wakil presiden, pembatasan masa jabatan presiden, pengaturan hubungan kekuasaan antara presiden dan DPR dan pengaturan pada kekuasaan presiden.

\section{PEMILIHAN PRESIDEN}

Pasca perubahan UUD 1945, ketentuan mengenai pemilihan presiden di Indonesia diatur dalam pasal 6A ayat (1) UUD 1945 yang isinya menyebutkan "Presiden dan Wakil Presiden dipilih dalam satu pasangan secara langsung oleh rakyat". Perubahan ketentuan dalam memilih Presiden dan Wakil Presiden secara langsung merupakan babak baru bagi perkembangan politik dan demokrasi di Indonesia, karena sebelumnya pemilihan presiden selalu dilakukan oleh Majelis Permusyawaratan Rakyat (MPR).

Konsekuensi adanya ketentuan tersebut sekaligus merekonstruksi konsep kedaulatan MPR sebagai pelaksana sepenuhnya kedaulatan rakyat. Kedaulatan dalam pembentukan pemerintahan (dalam hal ini Presiden dan Wakil Presiden) sepenuhnya berada di tangan rakyat. Presiden tidak lagi menjadi mandataris MPR yang harus tunduk dan bertanggungjawab kepada MPR, tetapi Presiden bertanggung jawab secara langsung kepada rakyat yang memilihnya. Karakteristik dasar ini merupakan prasarat institusional sebuah negara yang menganut sistem pemerintahan presidensial.
Konstruksi pemilihan Presiden pasca amandemen UUD 1945 yang dilakukan secara langsung di Indonesia relatif cukup rumit dibandingkan dengan negara lain yang menganut sistem pemerintahan presidensial dengan dua partai seperti yang dijalankan di Amerika, partai politik tidak perlu melakukan koalisi untuk mengajukan calon Presiden. Calon yang diajukan oleh partai politik sudah pasti tidak akan melebihi dua calon. Presiden dan Wakil Presiden terpilih akan membentuk kabinet yang diisi oleh orang-orang yang berasal dari partai politik yang mendukungnya. Sedangkan partai politik yang calonnya kalah akan menjadi oposisi di parlemen. Konstruksi seperti ini lebih simple dibanding dengan sistem multi partai yang dianut di Indonesia.

\section{KEKUASAAN PRESIDEN}

Sejak kemerdekaan 17 Agustus 1945 sampai sekarang, kekuasaan Presiden di Indonesia mengalami pasang surut. Pada tahun 1999 sampai tahun 2002 MPR melakukan perubahan terhadapUUD 1945. Hasil dariperubahantersebut salah satunya adalah mereduksi kekuasaan presiden. Perihal yang sangat mendasar dari perubahan tersebut terhadap kekuasaan presiden adalah dengan tidak berlakunya lagi penjelasan UUD 1945. Konsekuensinya, Presiden bukan lagi mandataris MPR. Selain itu, ketentuan mengenai presiden sebagai kepala negara sekaligus sebagai kepala pemerintahan juga ditiadakan.

Hasil dari perubahan tersebut kalau dicermati telah menyebabkan pengurangan pada kekuasaan Presiden. Pada perubahan tahap pertama dan kedua, ketentuan tersebut terjadi perubahan yang sangat mendasar yakni pada pasal 5 Ayat (1) UUD 1945 dinyatakan presiden berhakmengajukan undang-undangkepada DPR. Selanjurnya Pasal 20 Ayat (1) juga menegaskan bahwa DPR memegang kekuasaan membentuk undang-undang, sehingga berdasarkan perubahan tahap pertama dan kedua UUD 1945, kekuasaan membentuk undang-undang itu dialihkan dari presiden kepada DPR.

Pengalihan, pengurangan dan pembatasan terhadap kekuasaan Presiden pasca perubahan menyebabkan kekuasaan presiden sekarang lebih kecil dibandingkan sebelum UUD 1945 diamandemen. Tetapi perlu juga diperhatikan, sistem pemerintahan presidensial tidak menghendaki adanya kekuatan suatu lembaga 
sebelum UUD 1945 diubah, dipegang presiden secara mutlak tanpa perimbangan atau kontrol dari lembaga negara lain. Pasca perubahan UUD 1945, kekuasaan-kekuasaan presiden tersebut dibatasi. Kekuasaan menyatakan perang, membuat perdamaian, serta membuat perjanjian internasional yang menimbulkan akibat luas dan mendasar, dilakukan dengan persetujuan DPR. Kekuasaan untuk mengangkat dan menerima duta dan konsul harus dilakukan dengan pertimbangan DPR. Kekuasaan memberikan amnesti dan abolisi dilakukan dengan memperhatikan pertimbangan DPR.

Sedangkan terkait dengan menterimenteri negara, kekuasaan presiden dibatasi dengan ketentuan bahwa pembentukan, pengubahan, dan pembubaran kementerian negara diatur dengan undang-undang. Dengan demikian, yang nantinya akan diatur adalah institusi kementeriannya yang meliputi tata cara atau syarat-syarat pembentukan, pengubahan, dan pembubarannya, bukan menterinya yang merupakan kewenangan presiden untuk mengangkat dan memberhentikan. Ketentuan tentang kementerian negara inilah yang RUU-nya saat ini sedang dilakukan pembahasan oleh DPR bersama pemerintah.

\section{PERTANGGUNGJAWABAN POLITIK PRESIDEN PASCA AMANDEMEN UUD 1945}

Bercermin pada kelemahan yang terdapat pada UUD 1945 sebelum diamandemen, pada tahun 1999-2002 MPR melakukan perubahan terhadap UUD 1945. Salah satu perubahan penting dalam UUD 1945, terkait dengan sistem pemerintahan yang dianut oleh Indonesia. Sebagaimana dalam pembahasan sebelumnya, sistem pemerintahan yang dianut oleh Indonesia setelah perubahan UUD 1945 adalah sistem Presidensial. Berlakunya sistem ini salah satunya ditandai dengan pengaturan dalam konstitusi yang menyebutkan bahwa Presiden dan wakil Presiden dipilih secara langsung oleh rakyat dalam pemilihan umum. Walaupun UUD 1945 setelah perubahan tidak menegaskan tentang pertanggungjawaban politik presiden, adanya ketentuan tersebut secara otomatis merekonstruksi pola pertang-gungjawaban politik presiden yang sebelumnya dilakukan kepada MPR menjadi kepada rakyat yang memilihnya. Pendapat ini sejalan dengan uraian yang dikemukakan oleh
Jimly Asshidiqqie tentang ciri dari sistem pemerintahan presidensial, yang menyebutkan: Presiden dan Wakil Presiden tidak bertanggung jawab kepada lembaga politik tertentu, melainkan langsung bertanggungjawab kepada rakyat. Karena itu, lazimnya ditentukan bahwa presiden dan wakil presiden itu dipilih oleh rakyat secara langsung ataupun melalui mekanisme perantara tertentu yang tidak bersifat perwakilan permanen sebagaimana hakikat lembaga parlemen. Tanggung jawab pemerintahan berada di pundak presiden, dan oleh karena itu presiden-lah padaprinsipnyayangberwenang membentuk pemerintahan, menyusun kabinet, mengangkat dan memberhentikan para Menteri serta pejabat-pejabat publik yang pengangkatan dan pemberhentiannya dilakukan berdasarkan political appointment. Karena itu, dalam sistem ini biasa dikatakan concentration of governing power and responsibility upon the president (pemusatan dari kekuasaan pemerintah dan tanggung jawab di atas presiden). Di atas presiden tidak ada institusi lain yang lebih tinggi, kecuali konstitusi. Karenanya, dalam sistem constitutional state, secara politik presiden dianggap bertanggung jawab kepada rakyat, sedangkan secara hukum ia bertanggung jawab kepada konstitusi (Ashidiqie, 1985:162-163).

Pendapat yang sama juga dikemukakan oleh salah seorang pakar politik yaitu Rusadi Kantaprawira yang menegaskan:

Sesungguhnya di dalam sistem presidensial yang sekarang dianut oleh Indonesia, dimana presiden dipilih langsung oleh rakyat bahkan lebih langsung dibanding dengan Amerika yang dipilih oleh electorate, maka presidenitu bertanggungjawab kepada konstituen-nya atau para pemilih yaitu rakyat atau elektorate yang disimbolkan oleh penerimaan mereka dengan memilih kembali presiden incumbent untuk masa jabatan yang masih diperkenankan. Di negara Indonesia presiden dipilih dengan masa jabatan dua 2 kali sedangkan di Amerika 10 tahun. Dengan demikian kita lihat bahwa pertanggungjawabannya ini menjadi pertanggungjawaban politik. (Kantaprawira, wawancara tanggal 3 Mei 2009) 
kebijakan yang dikeluarkan dapat disetujui oleh DPR, sebaliknya DPR sebagai pemegang kendali akan memanfaatkan kesempatan tersebut demi kepentingan partai politik ataupun kepentingan pribadi. Alhasil, kebijakan yang dihasilkan sudah barang tentu tidak berkualitas dan bersifat elitis. Hal ini tentu tidak sejalan dengan prinsip pertanggungjawaban politik presiden kepada rakyat.

Faktor penyebab ketidakseimbangan hubungan antara Presiden dengan DPR dalam sistem Pemerintahan Presidensial yang dianut oleh Indonesia, dikarenakan Indonesia menganut asas distribution of power dalam pembagian kekuasaan. Jika pengaturan hubungan tersebut tidak terkonstruksikan dengan baik, menyebabkan kecenderungan terjadinya penumpukan kekuasaan pada satu tangan. Oleh karena itu sudah saatnya kita meninjauulang pengaturan hubungan kekuasaan antar Presiden dan DPR berdasarkan perspektif yang lain sebagaimana seharusnya dalam sistem presidensial.

Untuk dapat mewujudkan model separation of power dalam hubungan antara Presiden dan DPR di negara kita, maka sebaiknya perlu dilakukan reposisi terhadap kedua cabang kekuasaan tersebut. Dalam pembentukan undangundang kekuasaan sebaiknya tetap berada di tangan DPR sebagai lembaga legislatif tanpa harus ada keterlibatan dari pemerintah. Tetapi sebagai upaya untuk mengimbangi kekuasaan tersebut, presiden diberikan kekuasaan untuk mem-veto suatu rancangan undang-undang yang diajukan oleh DPR jika presiden tidak setuju terhadap rancangan undang-undang tersebut. Sedangkan untuk penyusunan anggaran sebaiknya kekuasaan diberikan kepada presiden dan DPR diberi kekuasaan untuk melakukan pengawasan. Persetujuan ataupun penolakan yang dilakukan oleh DPR terhadap anggaran yang diajukan oleh pemerintah merupakan bagian dari pengawasan, tanpa harus ikut merumuskan atau menyusun anggaran tersebut. Persetujuan ini juga perlu memiliki pengaturan dalam bentuk undang-undang yang dibuat oleh DPR, maksudnya, pertama menjadi pedoman bagi presiden untuk menyusun APBN dan; kedua, menjadi landasan bagi DPR untuk menyetujui atau menolak usulan RAPBN dari pemerintah.

Selain itu, hubungan antara Presiden dengan DPR juga semakin rumit manakala Indonesia menganut sistem multipartai. Menurut Mainwaring, seorang ahli konstitusi politik, sistem multipartai dan sistem pemerintahan presidensial adalah kombinasi yang sulit untuk membuat sebuah pemerintahan demokratis. Kesulitan ini terletak bukan saja pada masalah tidak mudahnya mencapai konsensus antara dua lembaga negara, yakni Presiden dan DPR, tapi juga diantara kekuatan di DPR sendiri. Setidaknya ada dua tingkat negoisasi dan lobi yang harus dikerjakan, yakni di dalam kongres, dan didalam hubungan antara kongres dan presiden. Dan yang lebih penting lagi, dalam presidensialisme, tidak ada insentif optimal bagi kekuatan di kongres atau DPR untuk menyepakati kebijakan yang akan diambil Presiden. Tidak ada misalnya tawaran bagi kekuatan di pihak oposisi untuk menjadi anggota kabinet sebab dalam presidensialisme yang menentukan anggota kabinet pada dasarnya merupakan hak prerogatif presiden.

Pemilihan umum pada tahun 2004 yang diikuti oleh 24 partai politik, hasilnya tidak melahirkan pemenang mayoritas di DPR. Walaupun dalam sistem presidensial kedudukan presiden kuat, faktanya presiden dan wakil presiden terpilih tidak selalu didukung suara mayoritas di parlemen. Menurut Bob Sugeng:

Pola pemilihan presiden di Indonesia dilakukan dengan menggunakan sistem radikal yang tidak ada di mana-mana. Dalam pemilihan umum, pemilihan presiden dipisahkan dengan pemilihan parlemen itu riskan, karena kemungkinan calon yang didukung oleh partai kecil bisa menang, yang dapat kita saksikan pada pemilihan presiden tahun 2004 dimana SBY menang dengan dukungan partai-partai kecil. Keadaaan ini dapat menyebabkan ketidakstabilan dalam pemerintahan. Seringkali saya kemukakan di mana-mana, bahwa pemerintahan SBY butuh political magic untuk menyelamatkan pemerintahannya. Apa itu political magicnya? wakil presiden yaitu Jusup Kalla yang dipilih SBY yang pada waktu itu tidak disenangi oleh partai Golkar bahkan dianggap indisipliner karena bergabung dengan SBY, justru menjadi ketua Partai Golkar. Itulah yang dimaksud dengan political magic-nya. Kalau anda simak, bulan-bulan awal ketika SBY memerintah itu mendapatkan tantangan luar bisa dari parlemen, menghadapi ancaman interpelasi penggantian Pangab, angket 
kenaikan BBM dimana Golkar pada saat itu masih berada di luar pemerintahan. Untungnya pada saat itu JK terpilih menjadi ketua partai sehingga Golkar berpaling dari oposisi menjadi pendukung pemerintah. (Sugeng, wawancara tanggal 5 Mei 2009)

Kekuatan yang terpolalarisari di DPR mendorong presiden untuk melakukan koalisi dengan partai lain diluar partai pemerintah. Konsekuensinya, sedikit banyak kabinet akan diisi oleh menteri-menteri yang berasal dari partai politik yang menjadi pendukung pemerintah. Dengan pola seperti ini, presiden berharap kebijakan yang dikeluarkannya akan mudah disepakati di tingkat parlemen. Tetapi perlu menjadi perhatian, koalisi yang dibangun dalam sistem presidensial yang dipadukan dengan sistem multipartai tidak memberikan jaminan akan bersifat permanen. Setiap saat partai politik dapat menarik diri dari koalisi dan berbalik menjadi oposisi ketika kepentingan partai politik menjadi yang utama. Sehingga kebijakan Presiden sedikit banyak akan diwarnai oleh upaya untuk mempertahankan koalisi antar partai politik untuk menjaga kekuasaannya. Sistem seperti ini tentu tidak akan membentuk suatu pemerintahan yang solid, sebagaimana dikemukakan oleh Rusadi Kantaprawira sebagai berikut:

Sistem presidensial gaya Amerika diterapkan secara efektif pada masa kabinet SBY dengan segala macam kecirian dan fenomena-fenomena yang kita kenal menjadi kompromistis, ditafsirkan berjiwa parlementer. Padahal presiden dipilih oleh rakyat, memperoleh mandat dari rakyat, tetapi ketika membentuk kabinet, presiden sangat ragu-ragu dan dipengaruhi oleh eksistensi politik yang mengitarinya. Karena jiwa presidensialime seperti yang dilakukan di AS atau negara-negara Amerika latin yang dipengaruhi dan yang terpengaruh oleh AS ternyata asumsi-asumsinya di Indonesia tidak terpenuhi. Di AS sistem presidensial didukung dengan dua partai, diAmerika Latin satu partai dan Indonesia multi partai yang amat sangat terfragmentasi dan sukar untuk mencalonkan presiden. Tidak ada satupun parpol yang secara utuh mencalonkan diri, kalaupun ada, patnernya atau wakilnya juga harus dari partai lain untuk membentuk pemerintahan yang kuat. Sesuatu yang pasti tidak akan melahirkan keutuhan, soliditas, stabilitas, tidak kompromistis, sikap yang tegas dan tidak ragu-ragu. Sebenarnya mungkin presidennya tidak bersikap tidak ragu-ragu tetapi sistem menyebabkan presiden menjadi ragu-ragu. (Kantaprawira, wawancara tanggal 3Mei 2009)

Untuk dapat mewujudkan sistem dua partai di Indonesia seperti Amerika sangat boleh jadi, tidaklah realistis mengingat kemajemukan masyarakat dan bangsa Indonesia. Suryama M. Sastra salah satu anggota DPR/MPR RI dari fraksi PKS berpendapat:

Orang mencampur adukkan multi partai dalam masyarakat dengan multipartai dalam pemilu dan parlemen. Menurut saya biarkan saja multipartai berkembang, karena upaya untuk membatasi partai sekarangpun sudah dilakukan melalui parlementary threshold. Biarkan multi partai hidup di masyarakat tetapiaturan pemilumembatasijumlah partai tersebut. Saya rasa saat ini Indonesia belum siap menggunakan dua atau tiga partai. Karena masyarakat kita baru melek politik. Kita tidak bisa mengabaikan real politik, ini kesempatan yang paling berharga kita merasakan proses transpormasi yang begitu cepat, dimana rakyat mendemonstrasikan kekuasaannya dengan menjungkirbalikkan kekuasaan sekehendak hatinya. (M. Sastra, wawancara tanggal 3 April 2009)

Terlepas dari kemungkinan tersebut, upaya untuk menyederhanakan jumlah partai politik sangat diperlukan jika Indonesia bermaksud menerapkan sistem presidensial secara murni. Penciutan jumlah partai itu dapat dilakukan asal saja direkayasa agar hal itu terjadi secara alamiah, bukan dipaksakan secara tidak demokratis. Pilihan untuk menggunakan sistem distrik maupun proporsional dengan treshold tetap harus berpedoman pada landasan kultural maupun sosiologis bangsa Indonesia. Permasalahannya tinggal pada political will dari pembuat kebijakan untuk menentukan sistem pemilihan akan digunakan di Indonesia. Selama ini kebijakan tentang sistem pemilihan anggota DPR yang digunakan adalah sistem campuran yang sama sekali tidak efektif mengurangi jumlah partai peserta pemilu. Walaupun pada tahun 2004 diberlakukan pembatasan melalui electoral 
treshold sebanyak 3\% pada kenyataannya jumlah partai yang menjadi kontestan pemilu bukan menjadi sedikit tetapi malah semakin banyak. Pada pemilu tahun 2009 jumlah partai politik peserta pemilu naik hampir seratus persen.

Selanjutnya, untuk mengetahui bagaimana mekanisme pertanggungjawaban politik presiden kepada rakyat, menurut Suryama M. Sastra:

Pertanggung jawaban politik terkait karena presiden dipilih secara langsung oleh rakyat. Dan sebetulnya sebutan pertanggungjawaban politik itu cenderung abstrak, karena satu-satunya yang kongkrit dari pertanggungjawaban politik itu adalah daur pemilu lima tahunan, selebihnya itu abstrak atau disalurkan melalui wakil rakyat. Dan ketika pertanggungjawaban politik disalurkan lewat wakil rakyat, maka akan terjadi penyempitan, pembelokan, manipulasi dan penunggangan. Bisa saja mereka yang menjadi penyalur atau wakil rakyat atas nama rakyat, atas nama pertanggungjawaban politik presiden. Sesuatu dalam konteks yang dapat dilakukan melalui proses penyusunan anggaran, legislasi maupun pengawasan melalui interest partai bisa atau melalui yang lain seperti pos menteri, resufle kabinet bahkan sampai pengisian pejabat BUMN. Memang menjadi absurd istilah pertanggungjawaban politik kecuali lima tahunan (M. Sastra, wawancara tanggal 3 April 2009).

Mekanisme pertanggungjawaban politik semacam ini bukan berarti juga tidak mengandung kelemahan. Pertanggungjawaban politik akan menjadi sulit dimintakan ketika masa jabatan seorang presiden dibatasi oleh konstitusi (misalnya dua periode). Dalam masa jabatan terakhir, presiden kurang memiliki insentif untuk melaksanakan mandat dari rakyat, sebab kalaupun ia dapat melaksanakan mandatnya dari rakyat sesuai yang diharapkan, tidak ada reward baginya atas sukses tersebut. Sukses ataupun gagal ia akan tetap harus mengakhiri jabatannya. Dalam kondisi seperti ini, ada peluang bagi presiden untuk tidak bertanggungjawaban atas mandat yang diberikan rakyat terhadapnya. (Mujani dalam CPSS, 2002:7)

Oleh karena itu, rumusan pembatasan kekuasaan terhadap presiden dengan menentukan masa jabatan dalam konstitusi perlu ditinjau kembali. Jika konstitusi menentukan bahwa kedaulatan untuk membentuk pemerintahan berada di tangan rakyat, maka seharusnya pembatasan kekuasaan melalui masa jabatan tidak lagi diperlukan. Terpilihnya seorang presiden pada periode berikutnya dikarenakan rakyat merasa bahwa presiden dapat menjalankan pemerintahan dengan baik dan rakyat menerima pertanggungjawaban politik presiden.

Pendapat ini sejalan dengan kritik yang dikemukan oleh Juan J. Linz terhadap sistem pemerintahan presidensial yang menyebutkan:

Karena masa jabatan presiden sudah ditetapkan berapa lama, Linz mengklaim sistem presidensialisme kurang fleksibel dibandingkan dengan sistem parlementer. Pembatasan masa jabatan itu justru membuat kekakuan dalam sistem politik, karena itu kurang baik bagi kehidupan demokrasi. Ini berbeda pada parlementer, karena ada mekanisme mosi tidak percaya dan pembubaran kabinet oleh parlemen. Keberadaan eksekutif selalu tergantung pada kepercayaan yang diberikan parlemen. (Linz dalam Efriza, 2008:297)

Dari pemaparan di atas, dapat diketahui bahwa pasca amandemen UUD 1945 pertanggungjawaban politik presiden sangat dipengaruhi oleh sistem pemerintahan yang sekarang dianut oleh Indonesia. Pertanggungujawaban politik presiden yang dilakukan kepada rakyat pasca amandemen dalam prakteknya tidak koheren dengan penataan sistem pemerintahan yang berlangsung selama ini dan inkonsisten satu sama lain. Pertanggungjawaban politik presiden tidak didukung oleh kuatnya kedudukan presiden, cheks and balance antara DPR dan presiden, sistem pemilihan umum, sistem kepartaian serta doktrin yang berupa kepantasan dan kebiasaan dalam dunia demokrasi. Sehingga, meskipun pertanggungjawaban politik presiden dilakukan kepada rakyat, tetapi karena sistemnya yang tidak mendukung, maka pada akhirnya akan melahirkan pemerintahan yang ragu-ragu, kompromistis, tidak solid dan tidak stabil.

Berdasarkan hal tersebut penulis mencoba mengajukan sebuah model yang mungkin dapat menjadi sebuah solusi untuk mewujudkan pertanggungjawaban politik presiden kepada rakyat yang seiring dengan sistem pemerintahan yang sekarang dianut oleh Indonesia. Model yang diajukan adalah sebagai berikut: 


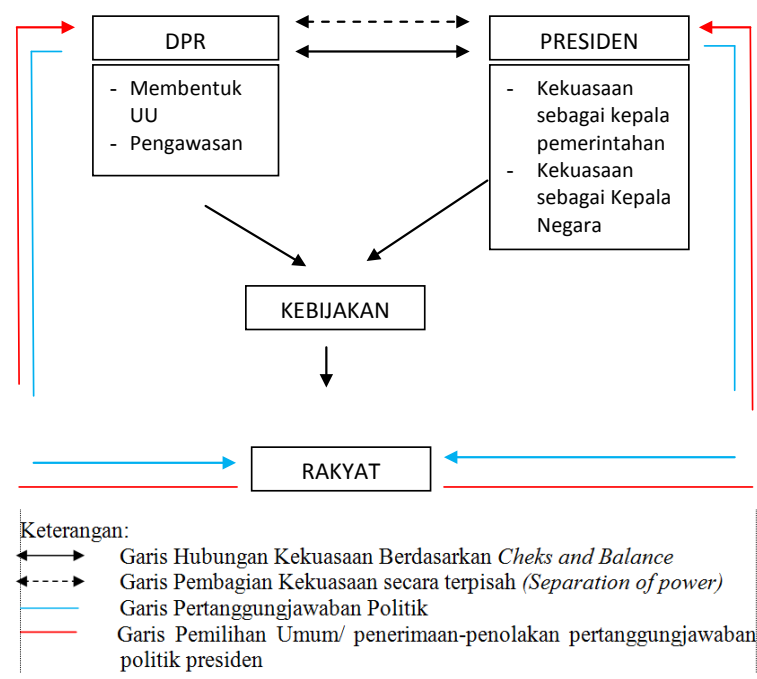

Gambar 2. Model Pertanggungjawaban Politik

\section{SIMPULAN}

Pertanggungjawaban politik presiden pasca amandemen UUD 1945 sangat dipengaruhi oleh sistem pemerintahan yang sekarang dianut oleh Indonesia. Pertanggungjawaban politik presiden yang dilakukan kepada rakyat pasca amandemen dalam prakteknya belum sejalan dengan penataan sistem pemerintahan yang berlangsung selama ini dan inkonsisten satu sama lain. Pertanggungjawaban politik presiden tidak didukung oleh cheks and balance antara DPR dan presiden, kuatnya kedudukan presiden, sistem pemilihan umum, sistem kepartaian serta doktrin yang berupa kepantasan dan kebiasaan dalam dunia demokrasi. Sehingga, meskipun pertanggungjawaban politik presiden dilakukan kepada rakyat, tetapi karena sistemnyayang tidak mendukung, maka pada akhirnya melahirkan pemerintahan yang ragu-ragu, kompromistis, tidak solid dan tidak stabil.

\section{DAFTAR PUSTAKA}

Ashidiqie, Jimly. 1985. Pergumulan Peran Pemerintah dan Parlemen Dalam Sejarah. Jakarta: UI Press.

Efriza. 2008. Ilmu Politik: Dari Ilmu Politik sampai Sistem Pemerintahan, Bandung: Alfabeta.

Firdaus,2007. Pertanggungjawaban Presiden Dalam Negara Hukum Demokrasi. Bandung: Yrama Widya.
Ghoffar,Abdul. 2009. Perbandingan Kekuasaan Presiden Indonesia Setelah Perubahan UUD 1945 dengan Delapan Negara Maju. Jakarta: Prenada Media Group.

Haris, Syamsudin. 2007. Konflik PresidenDPR:Dan Dilema Transisi Demokrasi di Indonesia. Jakarta: PT. Pustaka Utama Grafiti.

Laksono, Fajar dan Subardjo. 2006. Kontroversi Undang-Undang Tanpa Pengesahan Presiden. Yogyakarta: UII Press.

Mahfud M.D, Moh. 2000. Demokrasi dan Konstitusi di Indonesia; Studi tentang Interaksi Politik dan Kehidupan Ketatanegaraan. Jakarta: Rineka Cipta.

MPR RI, 2003. Panduan dalam Memasyarakatkan Undang Undang Dasar Republik Indonesia Tahun 1945: Latar Belakang, Proses, dan Hasil Perubahan Undang Undang Dasar Negara Republik Indonesia Tahun 1945, Jakarta: Sekretariat Jenderal MPR RI.

Moleong, Lexy J. 2006. Metodologi Penelitian Kualitatif. Bandung: Remaja Rosdakarya.

Ridhwan Indra, Muhammad dan Satya Arinanto. 1998. Kekuasaan Presiden dalam UUD 1945 Sangat Menonjol. Cet. I. Jakarta : Haji Masagung.

Suny, Ismail. 1986. Pergeseran Kekuasaan Eksekutif. Jakarta : CV. Kalindra.

Tim CPSS (ed). 2002. Gerak Politik Yang Tertawan: Menggagas Ulang PrinsipPrinsip Lembaga Kepresidenan. Jakarta: CPSS.

UUD 1945 dan Amandemennya.

Undang Undang Republik Indonesia Nomor 23 tahun 2003 tentang Pemilihan Presiden dan Wakil Presiden.

Vredenbregt, J. 1983. Metode dan Teknik Penelitian Masyarakat. Jakarta: PT Gramedia.

\section{Data Kualitatif}

Wawancara, Bob Sugeng Hadiwinata, Selasa, 5 Mei 2009, di Kampus Universitas 
Parahyangan, Pkl. 13.35 WIB sampai dengan selesai.

Wawancara, Rusadi Kantaprawira, Minggu, 3 Mei 2009, di Jl. Batu Indah, Pkl. 16.00 WIB sampai dengan selesai.
Wawancara, Suryama M. Sastra, Kamis, 3 April 2009, di Kantor PKPU cabang Condet Jakarta, Pk1. 14.00 WIB sampai dengan selesai. 